\title{
Research on Employee Incentive Problems in Modern Enterprise Management
}

\author{
Guo Pengkai, Kong Fansheng \\ Zaozhuang Vocational College of Science \& Technology \\ Tengzhou, 277500, China.
}

\begin{abstract}
This paper mainly has conducted the research to the incentive problem in modern enterprise management,which is based on Maslow's theory of needs. This paper firstly gives a brief overview of the Maslow's needs theory, and then carries on the analysis to the knowledge workers from the two aspects of the concept and characteristics . We studied on the deficiencies and current of Chinese enterprise knowledge staff motivation system in detail and then analysis the application value of Maslow theory of needs. Finally, the coping strategies and the problems should be paid attention to were studied on Maslow's needs theory.
\end{abstract}

Keywords-knowledge worker; needs ; motivation ; motivate factors

\section{INTRODUCTION}

Industrial society is the most important resources in the capital, and knowledge is the most important resource in the knowledge society. Into the era of knowledge economy, the enterprises in information and knowledge-based society environment, facing a sharp increase of knowledge and information, creative, abounds change, unpredictable knowledge-based work will be the work of the new economy the main form. Competition among enterprises, knowledge creation, use and value-added, reasonable allocation of resources, and ultimately depend on the carrier of knowledge, knowledge workers, the implementation, naturally, as a carrier of knowledge, the knowledge workers in the enterprise more and more important role, become an important part of enterprise value, quantity, quality and values of the knowledge-type employees will be enterprise in the fierce competition in the key factor for success.

\section{SUMMARY OF MALLOW'S DEMAND THEORY AND KNOWLEDGE WORKERS}

\section{A. Summary of mallow's hierarchy}

Marlow (Abraham Maslow, 1908-1908), was born in brooklime, New York, a famous American social psychologists, personality theorists and comparative psychologist. Was elected chairman of the American psychological Association in 1967.

Marlow's theory of human needs into physiological needs, security needs, social demand, respect the needs and self-actualization needs five levels, from low level to high level steps in turn:

1) Physiological needs. The minimum requirements for a person to maintain their own survival, mainly including eat, drink, clothing, shelter and transportation requirements.

2) Security requirements. Including the personal safety and property safety, life stability, demand from the pain, threat, or illness. Marlow believes that the organism is a pursuit of security mechanism. For general employees, safe and stable income, medical insurance, unemployment insurance and pension and other security requirements of compensation factor.

3) Social demand (need). Including the demand for friendship, love and belonging. When the physiological needs and safety needs are satisfied, these requirements will be highlighted, which produce incentive effect.

4) Respect the demand. Respect needs include derogatory sense of achievement and self value realization. Marlow believes that respect needs are met, can make the person is full of confidence to 
oneself, to work with enthusiasm, to experience the value of my own living.

5) Self-actualization needs. This is the highest level of demand, the realization of personal ideals, aspirations and reflected the highest level of subjective value, maximum potential. Achieve one's self-realization, problem solving ability, consciousness enhancement, good at independent thinking.

Five kinds of demand from low to high, according to the level gradually. In general, a certain level to satisfy the demand, will be to a high level of development, the pursuit of a higher level of demand is the force of the driving behavior, accordingly, get basic satisfy the demand is no longer a motivating force.

\section{B. The knowledgeable staff}

\section{1) The concept of knowledge workers}

American management guru Peter trucker first proposed the "knowledge workers" refers to "master and use symbols and concepts, use knowledge or information work". This article agree with Peter trucker to the knowledge staff, and combining with the characteristics of our employees and defines knowledge staff as the requirements of the job after a long time of education and training, must have higher professional technology and skill of employees, such as finance director and outstanding technical development personnel; Or to have the rich experience and outstanding in the industry management to employees, such as sales manager and general manager of company, etc. Definition of the concept of range determines the research object of this paper.

\section{ENTERPRISE KNOWLEDGE STAFF INCENTIVE}

\section{SYSTEM IN OUR COUNTRY PRESENT SITUATION AND THE}

\section{APPLICATION VALUE OF MARROW'S DEMAND THEORY}

A. status quo and problems of enterprise knowledge staff incentive system in China

1) The development situation of enterprise knowledge staff incentive system in China

Many enterprises have realized that there is to see the future society is dominated by knowledge society, knowledge staff is enterprise's most important resources, they have a positive start or are taking various measures to motivate knowledge workers, brings out their potential employees, creating rich value for the enterprise. Of course, the enterprise of knowledge staff incentive measures are not perfect, the current main incentives are as follows:

a) the high cash reward

b) the rising channel "ranking

c) a stock ownership plan pay

d) less informed decision-making

e) other incentives

B. At present our country enterprise knowledge staff incentive system of the main shortcomings

1) has not realized the particularity of knowledge staff incentive problems

Knowledge workers are working mainly with knowledge, symbols, they all have the knowledge and traditional staff there is a big difference, at the same time, they demand level is higher, self value realization, job satisfaction, such as demand is strong, therefore necessary to adopt different from general staff incentive measures to meet their different needs. However, in reality, many enterprises in China have no awareness of the different knowledge staff incentive problems, in the management of knowledge workers still adopts the traditional way, with the result that knowledge workers can not get the real motivation and potential can not be effectively mining, also not give full play to their creative and their enthusiasm are, thus, incentives to no avail.

2) ignore the knowledge staff training and development 
Knowledge economy era, science and technology update speed, the knowledge update cycle is extremely short, at the same time, enterprise competition has become fierce. Therefore, in this context, the knowledge staff to better adapt to competition, realize their own value, it need continuous learning and training, update their knowledge. In our country, with the development of market economy and the competition, enterprises of our country also started to realize the importance of knowledge staff training, training to them. But from a practical point of view, the enterprise training has such problems as blindly follow suit, the heavy form light result. Some companies to do serious research and analysis before training, so as to make the training pertinence and practicability, divorced from reality. Analysis have been carried out and some enterprise although, but since there is no corresponding training facilities, is often just the form please trainer to the enterprise to carry on the teaching, the training content and often the same way, leading to the tap.

\section{3) the distribution of compensation did not reflect the}

\section{distribution of human capital}

The knowledge economy era, knowledge workers become the most valuable capital, and it has become the consensus of the business community and academia. But because of this consensus is only stay in the old traditional concept, that is relative to the corporate profits, enterprise knowledge staff is only as input factors of production, is the enterprise profit creation tools, rather than as the owner of the company contribution to enterprise, at the same time, also didn't realize that the characteristics of human capital makes it has surplus teilhaberechte, seniority in the salary system of phenomenon is very common, the distribution system was not well reflect the value of knowledge, knowledge structure aging, failed to provide effective for some contribution employees still pay high wages, for young and middle-aged knowledge workers with outstanding contributions did not give and its contribution to match the salary.

\section{Maslow's hierarchy of needs for knowledge staff incentive system application value}

In maslow's demand theory, the more to a higher level of development, the more reflects the differences in people's overall development level and individual ability. The author thinks that the motive of one labor costs is to meet the demand of five levels, we can "machine" to laborer salary reward is divided into basic salary (physiological, safety requirements), education (respect requirements), title salary (respect requirements), length of service, safety and belonging needs), post salary (social and self value demand) and other different parts. At the same time we also noticed that workers of different jobs, maslow demand at all levels is different, even though the same laborer, at different times, maslow demand at all levels are also different, so, to adjust pay regularly, in order to achieve the purpose of retaining talent for a long time.

Based on maslow's demand theory of salary and compensation management system design, fully embodies the enterprise people-oriented thoughts, reflects the enterprise pay attention to employee personal development and the development of synchronous value, make the staff a sense of belonging, a sense of security, respect, in the end, the author expect as a result, employees in the company on the platform can be maslow's highest level of self value realization.

\section{MARLOW'S DEMAND THEORY OF COPING}

\section{STRATEGIES AND PROBLEMS THAT SHOULD PAY}

\section{ATTENTION TO}

\section{A. Marlow's demand theory of coping strategies}

1) Pay more attention to the training and development of knowledge workers

Enterprise training development cannot only stay in slogans and from stage, should not blindly follow, should be according to their own enterprise knowledge staff's demand for jobs with the corresponding training needs survey. From the source to ensure the usefulness and 
targeted training. Secondly, on the basis of the studies of the training, enterprises should choose corresponding training methods and contents, can use a kind of method also can be associated with a variety of methods.

2) To establish a scientific and reasonable

\section{performance appraisal system}

Performance appraisal is a formal employee evaluation system, it through the system method, the principle to assess and measure the working behavior of employees on the job and working effect, it is the enterprise manages communication between managers and employees is an important activity, the ultimate goal is to improve employee's performance, at the same time of realize the goal of enterprise management, improve employee satisfaction and sense of accomplishment future, eventually achieve "win-win" enterprises and personal development. Scientific and reasonable performance appraisal system are a key link remaining share incentive.

\section{3) Design staff career planning for the future}

, career planning refers to the organizations or individuals to personal development and organizational development, combining the decision of personal career personal factors. Organizational factors and social factors were analyzed, and enact related to personal life on the development of strategic ideas and plans. Knowledge-based employees according to their own knowledge, ability and career development needs to design the career development direction and roads, and design and consider themselves engaged in or in the future will be engaged in jobs, positions, for enterprise and individual is of great significance.

\section{CONCLUSION}

Modern enterprise competition in the final analysis is the talent competition, quality and quantity of human capital in the enterprise and even can control the fate of the enterprise. How to motivate employees, give play to exist employees potential, is the current of each enterprise's concerns. Every employee in the enterprise, the individual has a certain amount of human capital, but on each individual, the knowledge staff has the human capital on the number of beyond the general staff, and the knowledge staff has the basic features of human capital is decided to company, it is important to note, however, between enterprise and knowledge workers is a kind of principal-agent relationship under the condition of asymmetric information, the enterprise is very difficult to implement effective monitoring the process of knowledge staff's work, also not easy to simply work based on the results of its efforts to make the right evaluation, therefore, the knowledge staff's incentive system design is especially important, this incentive system should not only depends on the careful design of economic compensation, should also be dependent on the careful design, the cost is relatively lower than economic compensation, namely for the knowledge staff incentive factors, the fourth level of marrow's hierarchy of needs and fifth levels are particularly important.

\section{REFERENCE}

[1] Xiaoming Zheng. Management knowledgeable staff [J]. Chinese and foreign management review, 2000, (10) : 38 a 40

[2] Gary. Livid et al. Human resources management (6th edition) [M]. Beijing: China remain university press, 1999.

[3] Peter Drucker,. The future that has ever happened [J]. The Futurist, Nov1998:16 to 18.

[4] Francis) HeRui than. Xiao-ming zheng. Management knowledgeable staff $[\mathrm{M}]$. Beijing: mechanical industry publishing house, 2000

[5] Woodourffe. Winning the Talent War [M]. John Wiley \& Sons, LTD, 1999.

[6] Xingcheng Wang. Lu Jichuan Xu Yaozong. Knowledge economy [M]. Beijing: China economic publishing house, 1998.

[7] Zhenlei Shi. Knowledge workers incentive mechanism research [D]. Beijing: remain university of Chinese academy of labor and personnel matters, and 2002.

[8] Yanming Zheng. Theory of consciousness is the root of ranking of officials, harm and control countermeasures $[\mathrm{J}]$. Journal of social science in jungle province, 2003, (5): 240-243. 
[9] Hongye Gao. Western economics (macro) (fourth edition) [M]. Beijing: China remain university press, 2007.563564.
[10] Huashan Tang, Weiqi Liu. Hui Yuan. Master of economics says [M]. Beijing: people's posts and telecommunications publishing house, 2009.207 208. 